\title{
Studi Tentang Tenun Ikat di Home Industry Telaga Sari Trenggalek
}

\author{
Ahmida Nikmaykhu Rohmah, Hapsari Kusumawardani, Endang Prahastuti \\ Universitas Negeri Malang, Jl. Semarang No. 5 Malang, Jawa Timur, Indonesia \\ *Penulis korespondensi, Surel: hapsari.kusumawardani.ft@um.ac.id
}

Paper received: 02-03-2021; revised: 12-03-2021; accepted: 21-03-2021

\begin{abstract}
Abstrak
Tenun ikat merupakan kain tradisional Indonesia yang diproduksi di berbagai wilayah nusantara. Satu-satunya penghasil tenun ikat di Kabupaten Trenggalek adalah Home Industry Telaga Sari Trenggalek. Fokus penelitian Tenun Ikat di home industry Telaga Sari Trenggalek meliputi; (1) Latar belakang berdirinya home industry Telaga Sari Trenggalek, (2) Produk tenun di home industry Telaga Sari Trenggalek, (3) Motif tenun di home industry Telaga Sari Trenggalek, (4) Proses pembuatan tenun di home industry Telaga Sari Trenggalek, (5) Profil pemasaran produk tenun di home industry Telaga Sari Trenggalek. Tujuan penelitian adalah mendeskripsikan Latar belakang berdirinya, Produk kerajinan tenun, motif tenun, proses pembuatan tenun, serta profil pemasaran kerajinan tenun di home industry Telaga Sari Trenggalek. Penelitian ini merupakan penelitian deskriptif dengan pendekatan kualitatif. Metode penelitian yang digunakan adalah triangulasi teknik. Berdasarkan temuan peneliti dilapangan diperoleh data; (1) Tenun ikat Telaga Sari merupakan budaya baru di Kabupaten Trenggalek; (2) Home industry Telaga Sari Trenggalek menghasilkan berbagai macam produk tenun; (3) Home industry Telaga Sari Trenggalek memiliki motif umum dan motif khas Trenggalek; (4) Proses pembuatan tenun ikat Telaga Sari memerlukan dua tahap persiapan; (5) Sistem pemasaran produk tenun ikat Telaga Sari menggunakan sistem pemasaran langsung dan sistem pemasaran tidak langsung. Kesimpulan dari penelitian ini adalah (1) Tenun ikat Telaga Sari merupakan budaya baru di Kabupaten Trenggalek yang dibawa oleh Bapak Rohmad Ismail yang berasal dari Kediri; (2) home industry Telaga Sari Trenggalek menghasilkan berbagai macam produk tenun yakni: kain tenun katun mesres, kain tenun sutra, kain tenun semi sutra, pashmina, dan sarung goyor; (3) home industry Telaga Sari Trenggalek memiliki berbagai macam motif umum yang biasa digunakan pada kain tenun dimana motif tersebut tidak memiliki makna khusus dan juga memiliki motif khas Trenggalek yang bila dikaitkan dengan kebudayaan Trenggalek memiliki makna khusus. Motif khas tersebut yaitu motif cengkeh, motif wajik dan manggis, dan motif southern paradise; (4) Proses pembuatan tenun ikat Telaga Sari memerlukan dua tahap persiapan yaitu tahap persiapan benang lungsi dan tahap persiapan benang pakan; (5) Sistem pemasaran produk tenun ikat Telaga Sari menggunakan sistem pemasaran langsung dan sistem pemasaran tidak langsung.
\end{abstract}

Kata kunci: studi; tenun ikat; Home Industry Telaga Sari

\section{Pendahuluan}

Tenun ikat merupakan salah satu keanekaragaman warisan budaya Indonesia yang harus dilestarikan karena dapat memperkaya corak khas bangsa Indonesia dengan motif dan coraknya yang beraneka ragam. Perbedaan letak geografis Indonesia yang terdiri dari beberapa pulau mengakibatkan keragaman jenis kain dan ragam hiasnya tersebut. Pendapat tersebut diperkuat dengan pernyataan Kartiwa (2007) bahwa: Keragaman kain-kain tradisional dihasilkan oleh perbedaan geografis yang mempengaruhi corak hidup setiap suku bangsa di Nusantara. Perbedaan iklim mempengaruhi flora dan fauna yang ada di lingkungannya juga mempunyai andil besar terhadap perbedaan gaya hidup dan mata pencaharian sebuah kelompok masyarakat, sehingga satu yang berbeda dengan yang lainnya. 
Tenun ikat merupakan kain tradisional Indonesia yang diproduksi di berbagai wilayah nusantara seperti Sumatra, Kalimantan, bali, Sulawesi, Lombok, Sumbawa, dan jawa. Tenun yang dihasilkannya pun berbeda-beda dan memiliki makna, nilai sejarah, dan teknik yang berbeda juga. Hal ini terlihat dari segi warna, ragam hias, serta jenis bahan yang digunakan. Keahlian bangsa Indonesia dalam membuat kain tenun dapat dilihat dari ragam hiasnya yang tidak terlepas dari makna dan nilai sejarah para leluhurnya dahulu.

Kabupaten Trenggalek memiliki tenun ikat dengan motif khas Trenggalek. Motif tersebut dibuat sesuai dengan imajinasi pengrajinnya. Imajinasi diambil dari lingkungan sekitar dimana 2/3 bagian dari luas Trenggalek merupakan daerah pegunungan yang kaya dengan aneka hasil bumi seperti cengkeh, singkong, durian dan manggis. Penghasil kerajinan tenun ikat di Kabupaten Trenggalek yaitu home industry Telaga Sari. Home industry Telaga Sari merupakan pioneer dan satu-satunya penghasil kain tenun ikat di Trenggalek. Proses pembuatan tenun ikat disini masih menggunakan Alat Tenun Bukan Mesin (ATBM).

Home industry Telaga Sari berdiri pada tahun 2015 dan bertempat di Desa Buluagung, Kecamatan Karangan, Kabupaten Trenggalek. Sejak mulai berdiri sampai saat ini Pak Rohmad sebagai pemilik Home industry sering mengikuti pameran-pameran yang diadakan pemerintah. Pemerintah mengadakan pameran guna memperkenalkan dan turut melestarikan produk UMKM Trenggalek kepada masyarakat sekitar.

Keunikan dari tenun ikat ATBM Telaga Sari terletak pada motif khasnya. Motif khas tenun disini berbeda dengan motif tenun dari daerah lain karena diambil dari hasil perkebunan Trenggalek. Proses pembuatan tenun ikat ATBM Telaga Sari tidak dapat dikerjakan seluruhnya di Trenggalek. Mengingat Trenggalek bukanlah daerah penghasil tenun sehingga sangat minim tenaga terampil untuk membuat kerajinan tenun ikat.

\section{Metode}

Penelitian ini merupakan penelitian deskriptif. Arikunto (2010) menjelaskan bahwa "penelitian deskriptif selalu memaparkan dan menggambarkan suatu hal, misalnya keadaan, kondisi, situasi, peristiwa, kegiatan dan lain-lain". Pendekatan yang digunakan dalam penelitian ini adalah pendekatan yang bersifat kualitatif. Sugiyono (2015) mengungkapkan "penelitian kualitatif bersifat deskriptif. Data yang terkumpul berbentuk kata-kata atau gambar, sehingga tidak menekan pada angka". Data yang diperoleh dalam penelitian ini dikumpulkan secara intensif dan sistematik berupa keterangan, penjelasan, atau dokumentasi yang berkaitan dengan kain tenun ikat di home industry Trenggalek. Pengumpulan data ini bertujuan untuk mengumpulkan informasi Latar belakang berdirinya home industry Telaga Sari Trenggalek, Produk tenun di home industry Telaga Sari Trenggalek, Motif tenun di home industry Telaga Sari Trenggalek, Proses pembuatan tenun di home industry Telaga Sari Trenggalek, Profil pemasaran produk tenun di home industry Telaga Sari Trenggalek.

Penelitian ini dilakukan di home industry Telaga Sari yang bertempat di jl. Raya Buluagung KM 4, Talun, Desa Buluagung, Kecamatan Karangan, Kabupaten Trenggalek. Penentuan lokasi penelitian yang bersumber di Home industry Telaga Sari ini berdasarkan pertimbangan bahwa Home industry tersebut merupakan satu-satunya produsen kain tenun ikat yang ada di Trenggalek. Sumber data/informan dalam penelitian ini adalah pengusaha tenun, pengrajin, dinas koperasi mikro dan perdagangan, dinas perindustrian dan tenaga kerja, dan budayawan yang ada di Kabupaten Trenggalek, yang dipilih secara purposif untuk mendapatkan data yang berkaitan dengan penelitian. Obyek dari penelitian ini adalah tenun 
ikat di Home industry Telaga Sari yang meliputi latar belakang berdirinya, produk tenun yang dihasilkan, motif tenun, proses pembuatan, serta profil pemasaran produk.

Metode pengumpulan data dalam penelitian ini menggunakan triangulasi teknik yang meliputi (1) Teknik Observasi, (2) Teknik Wawancara, dan (3) Teknik Dokumentasi. Semua data yang diperoleh kemudian dilakukan analisis data sesuai dengan tujuan yang ingin dicapai. Prosedur analisis data penelitian kualitatif menurut miles dan Huberman dalam (Sugiyono, 2015) menyatakan bahwa aktivitas dalam analisis data dilakukan secara interaktif dan terus menerus. Aktivitas dalam menganalisis data adalah reduksi data, penyajian data, dan penarikan kesimpulan.

\section{Hasil dan Pembahasan}

Berdasarkan data yang telah diperoleh, baik dari hasil observasi, wawancara, dan dokumentasi mengenai tenun ikat di home industry Telaga Sari Trenggalek. Pada pembahasan ini dipaparkan mengenai latar belakang berdirinya home industry Telaga Sari Trenggalek, produk kerajinan tenun di home industry Telaga Sari Trenggalek, motif kerajinan tenun di home industry Telaga Sari Trenggalek, proses pembuatan kerajinan tenun di home industry Telaga Sari Trenggalek, profil pemasaran kerajinan tenun di home industry Telaga Sari Trenggalek.

\subsection{Latar Belakang Berdirinya Home Industry Telaga Sari Trenggalek}

Tenun ikat merupakan budaya baru di Kabupaten Trenggalek. Kebudayaan tenun ikat dibawa oleh Bapak Rohmad Ismail yang berasal dari Kediri dengan mendirikan home industry Telaga Sari Trenggalek pada tahun 2015 di Jalan Raya Buluagung km 4, Karangan. Sejalan dengan pernyataan tersebut, Wiretno (2013) menjelaskan hasil amandemen keempat yang ditetapkan Majelis Permusyawaratan Rakyat pada 10 Agustus 2002, yang berbunyi "Kebudayaan bangsa ialah kebudayaan yang timbul sebagai buah usaha budinya rakyat Indonesia seluruhnya".

Seiring berjalannya waktu home industry Telaga Sari terus berkembang . Permintaan pasar terhadap produk tenun ikat Telaga Sari meningkat sehingga Bapak rohmad ismail mulai mencari karyawan untuk membantu menjalankan usaha tersebut. Saat ini Bapak Rohmad Ismail memiliki dua karyawan di home industry Telaga Sari Trenggalek dan untuk proses produksi dibantu oleh Tenun Kurniawan di Kediri. Bapak Rohmad Ismail mendaftarkan usaha miliknya dan membuat SIUP pada tahun 2016. Daftar usaha dan SIUP tersebut dibuat atas nama istri beliau yakni Ibu Fitri Murdiyanti.

\subsection{Produk Tenun di Home Industry Telaga Sari}

Home industry Telaga Sari Trenggalek menghasilkan berbagai macam produk tenun. Produk tersebut meliputi: kain tenun katun mesres, kain tenun sutra, kain tenun semi sutra, pashmina, dan sarung goyor. Perbedaan produk tersebut berdasarkan bahan dasar yang digunakan serta kegunaan dari produk itu sendiri. Karena berbeda bahan dasar dan kegunaan produk-produk di home industry Telaga Sari memiliki harga yang bervariasi.

\subsection{Motif Tenun di Home Industry Telaga Sari}

Berdasarkan temuan penelitian dilapangan mengenai motif tenun ikat Telaga Sari Trenggalek dapat disimpulkan bahwa motif yang digunakan memiliki ragam hias geometris, 
flora (tumbuhan), dan dekoratif. Motif-motif tenun di home industry Telaga Sari Trenggalek merupakan motif umum yang biasa digunakan pada kain tenun dan motif khas Trenggalek. Motif umum yang digunakan pada tenun ikat Telaga Sari Trenggalek yang termasuk dalam ragam hias geometris meliputi motif rang-rang, motif wajik, motif gunung-gunung, dan motif kotak-kotak. Motif umum yang termasuk dalam ragam hias flora atau tumbuhan meliputi motif bunga kuncup, motif bunga di taman, dan motif bunga setaman. Motif umum yang termasuk dalam ragam hias dekoratif yakni motif salur, motif balian, dan motif jet. Motif umum ini tidak memiliki makna khusus namun untuk motif khas Trenggalek jika dikaitkan dengan kebudayaan Trenggalek memiliki makna khusus.

Berikut ini makna khusus tiga motif khas tenun ikat ATBM telaga sari Trenggalek:

\subsubsection{Motif Cengkeh}

Kunian \& Prihatini (2016) menyatakan bahwa "Untuk menciptakan ragam hias tumbuhan tidak seluruhnya dituangkan dengan bentuk yang serupa dengan aslinya, namun distilir atau disederhanakan terlebih dahulu sehingga memberikan kesan baru". Motif cengkeh merupakan motif yang termasuk dalam ragam hias flora yaitu ragam hias yang menggunakan tumbuhan sebagai objek motifnya. Motif cengkeh terinspirasi dari buah cengkeh. Selain bentuk cengkeh pada motif cengkeh juga terdapat motif tambahan berupa garis lurus putus-putus yang terkesan seperti rintik hujan.

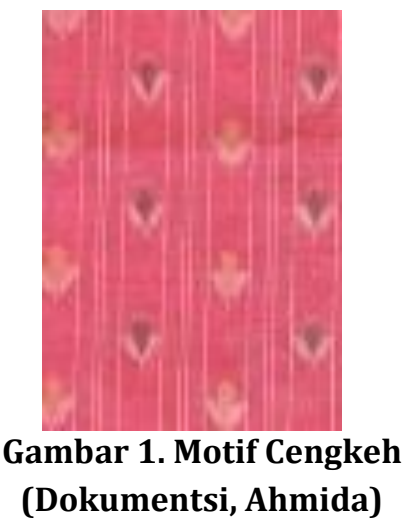

Tanaman cengkeh merupakan lambang kesuburan daerah Trenggalek. Dahulu pada masa pemerintahan Bapak Soetran tanaman cengkeh mengalami kejayaan di Kabupaten trenggalek. Bapak Soetran merupakan Bupati yang pernah menjabat pada zaman Trenggalek manunggal. Beliau menjabat pada tahun 1968-1974 (www.trenggalekkab.go.id). Saat itu Bupati memerintahkan masyarakat untuk menanam cengkeh di lahan yang mereka miliki kemudian cengkeh tumbuh subur terutama di daerah dongko (salah satu kecamatan di Trenggalek).

Cengkeh pada saat itu memiliki nilai jual yang tinggi sehingga masyarakat banyak yang hidup makmur dengan berpenghasilan dari tanaman cengkeh. Selain buahnya daun cengkeh juga bisa dijual namun dengan harga yang lebih murah. Banyak orang dari luar kota bahkan luar pulau berdatangan untuk mencari bibit cengkeh. Tumbuhan cengkeh menjadi produk unggulan terbesar di Trenggalek dan menjadikan Trenggalek terkenal dengan tanaman cengkeh. 


\subsubsection{Motif Manggis dan Wajik}

Motif manggis dan wajik merupakan salah satu motif khas Trenggalek yang menggunakan ragam hias dekoratif karena menggabungkan ragam hias geometris dengan ragam hias flora (tumbuhan). Motif utamanya adalah buah manggis dan bentuk wajik. Pada motif manggis dan wajik terdapat motif tambahan berupa garis miring yang diletakkan diantara motif utama. Sementara ini, motif manggis dan wajik hanya dibuat dengan warna background orange. Pemilihan warna orange ini tidak memiliki makna khusus hanya untuk menarik perhatian konsumen saja.

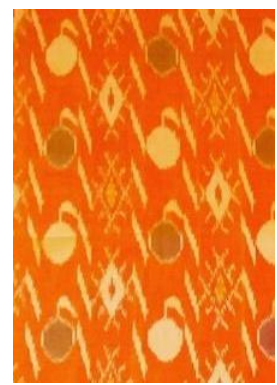

\section{Gambar 2. Motif Wajik dan Manggis \\ (Dokumentsi, Ahmida)}

Motif manggis memiliki kesamaan dengan motif cengkeh yaitu lambang kesuburan daerah Trenggalek yang digambarkan dengan hasil panen cengkeh dan manggis yang melimpah. Manggis merupakan produk unggulan di Kecamatan Watulimo Trenggalek. Kecamatan Watulimo terletak dibagian selatan kabupaten Trenggalek yakni di pesisir laut selatan yang berbatasan langsung dengan samudra hindia.

Kecamatan watulimo merupakan daerah dengan berbagai tempat wisata seperti pantai Prigi, pantai damas, pantai cengkrong, dan goa Lowo. Buah durian dan buah manggis dijadikan ikon wisata untuk menarik perhatian pengunjung. Pada musim buah manggis dan durian di pinggir jalanan watulimo akan sangat mudah ditemui buah tersebut dan para wisatawan akan meningkat ketika musim buat tersebut.

\subsubsection{Motif Southern Paradise}

Motif Southern Paradise merupakan motif khas Trenggalek dengan simbol perahu layar. Motif Southern Paradise di home industry Telaga Sari dibuat dalam dua macam yang pertama menggunakan symbol perahu dengan dua layar yang kedua menggunakan simbol perahu dengan tiga layar. Hal tersebut tidak memiliki makna khusus hanya agar lebih bervariasi saja.

Perahu layar ialah motif utama pada Motif Southern Paradise kemudian diberikan motif tambahan yakni garis miring yang diletakkan berjajar di atas simbol perahu layar. Selain motif utama dan motif tambahan juga terdapat center of interest pada bagian kiri kain berupa garisgaris sepanjang lebar kain agar ketika digunakan sebagai busana konsumen dapat lebih berkreasi dengan motif tersebut. 


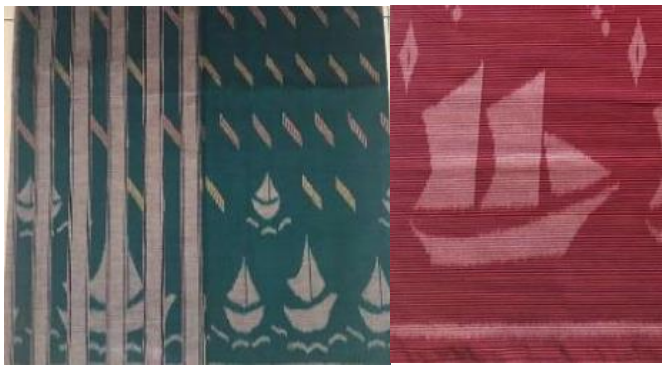

Gambar 3. Motif Southern Paradise

(Dokumentsi, Ahmida)

Southern Paradise merupakan tag line dari Trenggalek branding city yang diciptakan oleh Bramantya Yoga Widyaswara, Berto Mulia Wibawa, dan Muhammad Saiful Hakim dalam penelitiannya. Atas dasar itu peneliti merancang slogan untuk Kabupaten Trenggalek yaitu "Southern Paradise" yang memiliki arti surga yang terletak di selatan. Alasan menggunakan Southern karena Kabupaten Trenggalek terletak di bagian selatan provinsi Jawa Timur yang berbatasan langsung dengan pesisir selatan. Dari letak geografis Kabupaten Trenggaleklah gagasan tersebut menggunakan kata Southern. Selain itu selatan dalam kepercayaan masyarakat jawa kuno ditunggu oleh Batara Brahma yang merupakan dewa dengan gelar dewa kebijaksanaan. Kata Paradise yang berarti surga didapat dari keindahan alam yang dimiliki Kabupaten Trenggalek. Keindahan bagai di surga kesan pertama orang yang menikmati keindahan alam yang dimiliki Kabupaten Trenggalek (Widyaswara, et al., 2018). Lambang perahu layar pada motif Southern paradise menunjukkan letak geografis Trenggalek dimana bagian selatan dari daerah Trenggalek berbatasan langsung dengan samudra hindia selain itu juga melambangkan kekuasaan, kekuatan, dan semangat yang tidak pernah padam, begitupun dengan semangat rakyat Trenggalek untuk selalu hidup dengan memberikan kebermanfaatan bagi sesama manusia.

\subsection{Bahan yang Digunakan}

Bahan utama yang digunakan untuk membuat kain tenun ikat tradisional ialah benang dan pewarna. Benang dan pewarna yang digunakan di home industry telaga sari merupakan benga dan zat pewarna sintetis. Menurut Trisnayana, et al., (2016) bahan dasar yang digunakan untuk membuat tenun flores di home industry Ibu Yustina Nina menggunakan benang rayon, benang katun, dan benang sutra kemudian bahan pewarna yang digunakan ialah naphtol. Pada kain tenun donggala dahulu menggunakan warna-warni dari tumbuhan, tetapi sekarang menggunakan bahan pewarna sintetis. Benang yang dahulu digunakan adalah sutera asli namun sekarang banyak menggunakan benang rayon (Kartiwa, 2007). Berbeda dengan kain tenun donggala, pada kain tenun limar awalnya menggunakan benang katun dari kapas kemudian benang sutra. Benang katun dipakai pada lajur lungsi sedangkan benang sutra digunakan sebagai benang pakan. Di Palembang bahkan dikenal dengan pembudidayaan ulat sutra untuk diambil benangnya.

Dilihat dari beberapa wilayah yang menggunakan teknik tenun ikat pakan diatas seiring berjalannya waktu kain tenun beralih menggunakan bahan sintetis. Penggunaan bahan untuk membuat tenun di Home industry telaga sari apabila dibandingkan merupakan bahan-bahan yang tergolong baru karena menggunakan benang dan pewarna sintetis. Benang sintetis yang digunakan ada tiga macam yaitu benang katun, benang rayon, dan benang sutera sedang untuk bahan pewarna Home industry telaga sari menggunakan indhantren atau naphtol. Hal ini 
tergantung warna apa yang ingin dikehendaki. Penggunaan bahan-bahan sintetis tersebut merupakan upaya agar proses produksi lebih cepat dan efisien, namun sedikit mengurangi nilai tradisional.

\subsection{Proses Pembuatan Tenun di Home Industry Telaga Sari}

Proses pembuatan tenun di Home industry Telaga Sari menggunakan Teknik tenun ikat pakan dengan menggunakan alat tenun bukan mesin (ATBM) sehingga motif yang dihasilkan merupakan hasil dari pengikatan benang pakan dengan distorsi ke arah benang pakan atau horizontal. ATBM merupakan alat tenun tradisional yang lebih modern dari alat tenun tradisional lain seperti alat tenun gedhog. Menurut Djoemena (2000) alat tenun gedhog disebut juga dengan nama alat tenun gendong yang kemudian berkembang menjadi alat tenun tijak. Alat tenun tijak tersebut terus berkembang dan sekarang disebut ATBM.

Dalam proses pembuatan tenun ikat telaga sari memerlukan beberapa alat bantu selain ATBM. Alat bantu tersebut digunakan pada proses persiapan benang. Ada tiga belas tahapan proses yang harus dilalui untuk membuat tenun ikat Telaga Sari. Tiga belas tahapan ini dibagi dalam dua proses persiapan benang yakni persiapan benang lungsi dan persiapan benang pakan Keseluruhan tahapan proses pembuatan tenun ikat telaga sari meliputi: pencelupan benang lungsi, pemintalan benang lungsi ke kelos, proses skeer, pemintalan benang pakan pada kelos, proses reek, pemberian motif, pengikatan, pencelupan benang pakan, proses colet, proses oncek, proses mindah, pemintalan benang pada palet, dan menenun benang pakan dengan benang lungsi menggunakan ATBM.

Pada proses persiapan benang lungsi ada tiga tahapan yakni pencelupan benang lungsi, pemintalan benang lungsi ke kelos, dan proses skeer. Pencelupan benang lungsi yaitu proses mewarnai benang lungsi. Proses ini dikerjakan dengan bantuan bak, sarung tangan karet, sepatu boot, dan kompor. Pemintalan benang lungsi ke kelos yaitu proses memintal benang yang telah dikeringkan setelah proses pencelupan. Proses ini menggunakan alat yang bernama goben dan kelos. Benang yang telah dipintal pada kelos kemudian diletakkan pada jagrak. Peralatan pemintalan benang lungsi ke kelos adalah goben, dan kelos. Dan yang terakhir Proses skeer yaitu proses menggulung benang dari kelos yang ditata pada jagrak kealat yang berukuran besar yang bernama bum. Apabila benang lungsi telah tergulung pada bum, kemudian bum dipasang di ATBM dan benang lungsi siap ditenun. Peralatan yang digunakan pada proses skeer adalah kelos dan bum.

Pada proses persiapan benang pakan terdapat 10 tahapan yang meliputi pemintalan benang pakan pada kelos, proses reek, pemberian motif, pengikatan, pencelupan benang pakan, proses colet, proses oncek, proses mindah, pemintalan benang pada palet, dan menenun benang pakan dengan benang lungsi menggunakan ATBM. Tahap pertama adalah Pemintalan benang pakan pada kelos dimana benang yang akan digunakan sebagai benang pakan dibiarkan berwarna putih dan langsung dipintal dengan menggunakan alat goben ke kelos. Proses reek yaitu proses menggulung dan menata benang pakan pada bidangan untuk selanjutnya diberi motif. Peralatan yang digunakan adalah kelos, jagrak, dan bidangan. Proses pemberian motif dalam istilah jawa disebut disket. Proses ini dikerjakan dengan menggunakan penggaris, pensil, dan spidol. Pengikatan yaitu proses mengikat benang dengan bahan yang tidak menyerap air sehingga dipilih tali rafia. Selain tali rafia alat yang diperlukan yaitu bidangan, penggaris, pensil, dan spidol. Pencelupan benang pakan yaitu proses pewarnaan benang pakan. Bahan 
pewarna yang digunakan ialah naphtol atau indantren. Pemilihan bahan pewarna sesuai dengan warna yang dikehendaki setelah pencelupan selesai benang dijemur namun tidak boleh sampai terlalu kering. Peralatan yang digunakan iyalah tempat zat warna dan kocoran. Proses oncek yaitu proses melepas tali rafia yang diikatkan pada benang pakan. Alat yang digunakan untuk oncek yaitu cutter. Proses mindah yaitu proses mengurai benang pakan untuk persiapan dijadikan umpan ketika proses tenun. Umpan yang dimaksud yaitu benang pakan yang telah digulung pada palet yang kemudian dimasukkan kedalam teropong. Pemintalan benang pada palet yaitu menggulung benang pakan yang sudah melalui semua proses dari pemintalan pada kelos sampai mindah dengan menggunakan goben dan palet. Setelah proses persiapan benang pakan selesai berarti benang pakan siap ditenun. Tahap terakhir untuk membuat kain tenun yaitu menenun dengan ATBM. Benang lungsi dan benang pakan yang telah melalui tahap persiapan benang siap ditenun menggunakan ATBM.

\subsection{Profil Pemasaran Tenun di Home Industry Telaga Sari}

Pemasaran adalah proses, cara, perbuatan memasarkan suatu barang dagangan dengan menyebar luaskan ke masyarakat. Menurut Sutisna dalam Babang dan Amunullah (2019) Komunikasi pemasaran dibutuhkan sebagai elemen yang penting dalam dunia bisnis yang tidak bisa dipisahkan. Sistem pemasaran dibagi atas sistem pemasaran langsung, sistem pemasaran tidak langsung atau melalui perantara pihak ketiga. Selaras dengan penjelasan sistem pemasaran diatas dapat disimpulkan sistem pemasaran yang dilakukan pemilik home industry Telaga Sari diantaranya: 1) Sistem pemasaran langsung yaitu dimana Bapak Rohmad Ismail atau pegawainya berkomunikasi langsung dengan target konsumen untuk melakukan penjualan. biasanya bertemu melalui pameran atau konsumen langsung datang ke showroom tenun ikat telaga sari. 2) Sistem pemasaran tidak langsung juga dilakukan oleh pemilik Home industry Telaga Sari dengan cara memasarkan secara online melalui media sosial seperti facebook, instagram, dan whatsapp juga melalui situs belanja tokopedia. Produk yang dibeli secara online akan dikirim melalui ekspedisi yang diinginkan konsumen bisa melalui jnt, jne, atau pos Indonesia. Selain memasarkan secara online pemasaran tidak langsung juga dilakukan dengan konsiyasi atau menitipkan barang di Galeri Gemilang. Daerah persebaran pemasaran produk tenun ikat ATBM Telaga Sari meliputi wilayah Kabupaten Trenggalek, luar Kabupaten Trenggalek (Tulungagung, Madiun, Madura), luar pulau jawa (Kalimantan dan Sulawesi) dan luar negeri (Malaysia).

Menurut pernyataan Babang \& Amunullah (2019) Faktor penghambat internal Sentra Tenun Prailiu yang pertama datangnya dari karyawan yang kurang memiliki motivasi kerja sehingga produksi kain tenun Sumba Timur tidak mencapai target. Yang kedua perusahaan sering mengalami kekurangan bahan yang digunakan oleh perusahaan untuk membuat kain tenun. Kedepannya home industry telaga sari perlu perhatian dari dinas terkait untuk meningkatkan SDM dan pemasaran agar lebih luas dan diterima oleh masyarakat. Sejalan dengan pernyataan diatas, dalam proses pemasaran tenun ikat telaga sari juga mengalami beberapa kendala diantaranya: 1) Ketika ada pesanan dalam jumlah besar, kapasitas produksi Home industry telaga sari kurang karena terbatasnya tenaga kerja. Tenun ikat telaga sari merupakan kain tradisional yang memerlukan waktu yang tidak singkat untuk memproduksi dalam jumlah banyak. 2) Minat seseorang untuk bekerja di bidang tenun rendah menyebabkan kurangnya tenaga ahli. Solusinya mencari dan menambah tenaga ahli dengan melatihnya terlebih dahulu. 3) Segmen pasar terbatas karena lebih diminati orang dewasa atau orang tua. Solusinya melakukan inovasi terhadap motif dan warna agar diminati semua kalangan. 4) 
Peran serta pemerintah untuk mengembangkan Home industry telaga sari yakni dari dinas komindag mengadakan pameran produk pada even-even di kabupaten trenggalek kemudian memberikan stand pameran gratis kepada Home industry telaga sari, menyediakan fasilitas galeri gemilang sebagai tempat menitipkan produk untuk dipasarkan secara gratis, dan memberikan pinjaman modal dengan bunga ringan dari bank yang bekerja sama dengan diskomindag.

\section{Simpulan}

\subsection{Simpulan}

Berdasarkan hasil temuan penelitian yang telah dilakukan oleh peneliti dilapangan. Maka dapat ditarik kesimpulan bahwa: 1) Tenun ikat Telaga Sari merupakan budaya baru di Kabupaten Trenggalek yang dibawa oleh Bapak Rohmad Ismail yang berasal dari Kediri. Home industry Telaga Sari mulai berdiri pada tahun 2015 di Jalan Raya Buluagung km 4, Karangan. Pada tahun 2016 home industry Telaga Sari didaftarkan sebagai perusahaan perorangan dan dibuatkan SIUP atas nama Ibu Fitri Murdiyanti. 2) Home industry Telaga Sari Trenggalek menghasilkan berbagai macam produk tenun yakni: kain tenun katun mesres, kain tenun sutra, kain tenun semi sutra, pashmina, dan sarung goyor. Motif tenun ikat Telaga Sari cenderung menggunakan ragam hias geometris, flora, dan dekoratif. Home industry Telaga Sari Trenggalek memiliki berbagai macam motif umum yang biasa digunakan pada kain tenun dimana motif tersebut tidak memiliki makna khusus dan juga memiliki motif khas Trenggalek yang bila dikaitkan dengan kebudayaan Trenggalek memiliki makna khusus. Tiga motif khas tersebut yaitu motif cengkeh, motif wajik dan manggis, dan motif southern paradise. 3) Proses pembuatan tenun ikat Telaga Sari memerlukan dua tahap persiapan yaitu tahap persiapan benang lungsi dan tahap persiapan benang pakan. Tahap persiapan benang lungsi meliputi: Pencelupan benang lungsi, Pemintalan benang lungsi ke kelos, dan Proses skeer. Tahan persiapan benang pakan meliputi: Pemintalan benang pakan pada kelos, Proses reek, Pemberian motif, Pengikatan, Pencelupan benang pakan, Proses colet, Proses oncek, Proses mindah, dan Pemintalan benang pada palet. Benang lungsi dan benang pakan yang telah melalui tahap persiapan benang tersebut selanjutnya siap ditenun menggunakan ATBM. 4) Sistem pemasaran produk tenun ikat Telaga Sari menggunakan sistem pemasaran langsung dan sistem pemasaran tidak langsung. Sistem pemasaran langsung melalui pameran dan pemesanan produk secara langsung di showroom. Sistem pemasaran tidak langsung dengan memasarkan secara online melalui media sosial seperti facebook, instagram, dan whatsapp dan juga melalui situs belanja online tokopedia. Selain memasarkan secara online pemasaran tidak langsung juga dilakukan dengan konsiyasi atau menitipkan barang di Galeri Gemilang.

\subsection{Saran}

Dari hasil penelitian dapat disarankan, mengenai tenun ikat di home industry Telaga Sari Trenggalek agar dapat terus berkembang dan lebih dikenal masyarakat luas yaitu: Terus mengembangkan motif yang sudah ada terutama motif khas Trenggalek agar lebih bervariasi sehingga tenun ikat Telaga Sari dapat dikenali dengan motif khas tersebut. Sebaiknya motif yang telah dibuat didokumentasikan dan diberi nama untuk memudahkan wisatawan atau masyarakat yang ingin mengetahui tenun ikat khas Trenggalek sehingga mudah dikenali. Pada dinas perindustrian dan tenaga kerja hendaknya memfasilitasi untuk mengadakan pelatihan tenun ikat terhadap masyarakat Trenggalek sehingga tenun ikat Telaga Sari dapat bertahan 
dan terus berkembang. Hendaknya lebih sering mengikuti pameran atau pelatihan-pelatihan yang diadakan oleh pemerintah Kabupaten Trenggalek guna mengembangkan usaha serta pemasaran produk tenun ikat Telaga Sari.

\section{Daftar Rujukan}

Arikunto, S. (2010). Prosedur penelitian: Suatu pendekatan praktik. Rineka cipta.

Babang, R. R., \& Rinata, A. R. (2019). Strategi Komunikasi Pemasaran Sentra Tenun Prailiu dalam Meningkatkan Penjualan Kain Tenun Sumba Timur. Jurnal Komunikasi Nusantara, 1(2), 82-89.

Djoemena, N. S. (2000). Lurik Gari-garis Bertuah. Jakarta: P.T. Ikrar Mandiri Abadi.

Kartiwa, S. (2007). Ragam kain tradisional Indonesia tenun ikat. Jakarta: Gramedia Pustaka Umum.

Kunian, D. (2016). Makna Ragam Hias Motif Nago Besaung Pada Kain Songket Palembang. JURNAL SITAKARA, 1(1).

Pemerintah Kabupaten Trenggalek. (2018). Sekilas Kabupaten Trenggalek. (online), https://www.trenggalekkab.go.id, diakses 27 Juli 2019)

Sugiyono, S. (2015). Metode Penelitian Kuantitatif Kualitatif dan R\&D. Bandung: Alfabeta.

Trisnayana, I. K., Suartini, L., \& Budiarta, I. G. M. (2016). Proses Pembuatan Tenun Flores Home Industri Ibu Yustina Nona di Desa Tanjung Benoa. Jurnal Pendidikan Seni Rupa Undiksha, 6(3).

Widyaswara, B. Y., Wibawa, B. M., \& Hakim, M. S. (2018). Perancangan Logo dan Slogan Kabupaten Trenggalek Sebagai Media City Branding. Jurnal Sains dan Seni ITS, 7(1), 23-25.

Wiretno, W. (2013). Eksistensi Tenun Ikat Bandar Kidul Kediri dalam Pembentukan Identitas Budaya Masyarakat Kota Kediri, (Online), (www.academia.edu/8849867/Tenun_Ikat_Bandar_Kidul_Kediri_Wiretno), diakses 25 januari 2020. 